\title{
Profitability and Determinants of the Choice of Commercialization of Non-Timber Forest Products in Kinshasa. Case of Salacia pynaertii De Wild, Gnetum africanum Welw, Pteridum centrali-africanum Hieron
}

\author{
Edwin Imfumu' ${ }^{1}$, Félicien Lukoki² \\ ${ }^{1}$ Institut Supérieur Agro-vétérinaire (ISAV) Saint Pierre Canisius, Kinshasa, Democratic Republic of Congo \\ ${ }^{2}$ Department of Biology, Faculty of Sciences, University of Kinshasa, Kinshasa, Democratic Republic of Congo \\ Email: edwinimfumu@gmail.com, felicienlukokiluyeye@yahoo.fr
}

How to cite this paper: Imfumu, E. and Lukoki, F. (2020) Profitability and Determinants of the Choice of Commercialization of Non-Timber Forest Products in Kinshasa. Case of Salacia pynaertii De Wild, Gnetum africanum Welw, Pteridum centrali-africanum Hieron. Open Access Library Journal, 7: e5997.

https://doi.org/10.4236/oalib.1105997

Received: December 12, 2019

Accepted: December 31, 2019

Published: January 3, 2020

Copyright $\odot 2020$ by author(s) and Open Access Library Inc.

This work is licensed under the Creative Commons Attribution International License (CC BY 4.0).

http://creativecommons.org/licenses/by/4.0/

\begin{abstract}
The paper presents the result of the profitability and determinants of the choice of commercialization of non-timber forest products in Kinshasa. This was achieved by means of questionnaire survey administered to 207 vendors of Salacia pynaertii, Gnetum africanum and Pteridumcentrali-africanum. The objectives were to identify the factors which determine the choice of commercializing each non-timber forest product (NTFP) and determine their profitability. Descriptive analysis of all variables collected through the questionnaire survey was undertaken followed by logistic regression of selected factors. Age and marital status determine the choice of commercialization of $S$. pynaertii, experience is the only explanatory factor determining the choice of $G$. africanum; age, marital status, market access, place of supply and level of income are explanatory factors determining the choice of commercializing $P$. centrali-africanum. The results of the daily financial calculations gave the profitability of the 3 NTFPs studied as follows: 5300 CDF (5.7 USD) and 41, $7 \%$ for $S$. pynaertii, $9300 \mathrm{CDF}$ (10 USD) and $86.9 \%$ for G. africanum; and 320 CDF (0.34 USD) and 32.2 for $P$. centrali-africanum.
\end{abstract}

\section{Subject Areas \\ Environmental Sciences}

\section{Keywords}

Non-Timber Forest Product, Salacia pynaertii, Gnetum africanum, Pteridumcentrali-africanum 


\section{Introduction}

From time immemorial, the diet of rural and urban populations in Africa has been based on plants and animal products taken from forest ecosystems [1] [2] [3]. Especially products from local plant species such as fruits, leaves, bulbs, kernels, roots, bark and bark extracts, which are part of non-timber forest products, represent an important part of people's daily diets, as well as traditional crafts or medicine [4] [5] [6].

In addition, non-timber forest products (NTFPs) contribute to the household economy by generating income and diversifying livelihood strategies [7] [8]. One major advantage of these products to the rural population is accessibility which makes it affordable even to those who have no land and/or no sufficient income [9] [10].

According to [2] there exist organized chains, cross-border and/or international marketing for several species with economic potentialities. [11] shows that more than 150 NTFPs are traded in various markets of Central Africa, the most important are: fish, honey, rubber, rattan, walnuts, mushrooms, caterpillars, leaves of Gnetum africanum, fruits of Piper guineensis, resins, essential oils, parts of plants or animals used in pharmaceutical industry. Unfortunately, the emphasis on these "major" NTFPs often masks the opportunities that could be accorded to several products of important cultural value [12].

We believe that the local value of a particular species may be an asset in favor of its promotion, knowledge of harvesting methods and rate, opportunities for transformation and commercialization and according to [4] even its domestication.

Despite the large number of ethnobotanical studies carried out in many regions of the Democratic Republic of Congo, there are still gaps of information on some species traded in markets of NWFPs in Kinshasa [1] [6] [8] [13] [14]. In addition, the informal nature of the use of these products explains the scarcity of data on their harvest, trade and the number of people involve in the activity [3] [7]. This is a major problem as the extraction of NTFPs is not without peril. [15] pointed out that the harvesting of NTFPs can have an adverse impact, especially when their rate of extraction is greater than the natural regeneration process, as it is often the case.

S. pynaertii, unlike G. africanum and P. centrali-africanum, is a species that unfortunately has the same problem, mentioned above, as many other NTFPs. To date, very little research has been done on its commercialization and even on the extraction rate. It is not an exaggeration to say that $S$. pynaertii is among the least NTFPs considered as "minor". [16] reported that in some parts of the DRC this plant has become scarce due to reduced fallow and excessive harvest for consumption. However, no information on its actual and/or potential contribution to the household economy exists.

It is in this perspective that this study aimed to analyze the profitability and the factors influencing the choice of commercialization of $S$. pynaertii compared 
renowned products: $G$. africanum and $P$. Centrali-africanum.

Since the potential value and importance of NTFPs was first mooted in the 1980s, many definitions emerged [12] but we considered that of [17] which states: "Non-timber forest products are non-timber biological products derived from forests, other wooded lands or from trees outside forests". This means that NTFPs can be harvested in the wild, or produced in forest or agroforestry plantations. Examples of NTFPs include products used as food and food additives (edible nuts, mushrooms, fruits, herbs, spices and condiments, aromatic plants, game meat), fibers (used in construction, furniture, clothing and utensils), resins, gums, and plant products and animals used for medicinal, cosmetic or cultural purposes [6] [17].

\section{Methods}

The survey was conducted in Kinshasa, particularly in Camp-Luka, Gambela, Ngaba, Pascal, Matadi-kibala and Selembao markets. Primary data was collected during from June $20^{\text {th }}$ to August $20^{\text {th }} 2015$ using Questionnaire which was administrated to vendors. In addition, personal observations at the study area level gave us the opportunity to describe some of the salient facts, to criticize the information obtained and to mature the reflection on the topic.

\subsection{Sampling}

We used the snowball sampling method. The method is relatively simple and useful when the researcher is having difficulty to find subjects for his research, especially when they are a minority population or a specific social category [18]. It is about asking the first person to indicate others who are concerned by the subject of the research. Asub-total of 69 vendors of $S$. pynaertii were identified. The same quota was applied for G. africanum and $P$. centrali-africanum. This led to a total of 207 respondents (Table 1 ).

The allocated quota of $G$. africanum and $P$. centrali-africanum is identical for all markets except for Pascal market because of its sales force which is at least double the other markets by NTFP studied (Figures 1-3).

Table 1. Distribution of vendors by site.

\begin{tabular}{ccccccc}
\hline \multirow{2}{*}{ Markets } & \multicolumn{2}{c}{ S. pynaertii } & \multicolumn{2}{c}{ G. africanum } & \multicolumn{2}{c}{ P. centrali-africanum } \\
\cline { 2 - 7 } & Freq. & $\%$ & Freq. & $\%$ & Freq. & $\%$ \\
\hline Camp Luka & 18 & 26 & 10 & 14.4 & 10 & 14.4 \\
Gambela & 4 & 5.7 & 10 & 14.4 & 10 & 14.4 \\
Ngaba & 9 & 13 & 10 & 14.4 & 10 & 14.4 \\
Masina Pascal & 25 & 36 & 19 & 27.5 & 19 & 27.5 \\
Matadi Kibala & 2 & 2.8 & 10 & 14.4 & 10 & 14.4 \\
Selembao & 11 & 15.9 & 10 & 14.4 & 10 & 14.4 \\
Total & 69 & 100 & 69 & 100 & 69 & 100 \\
\hline
\end{tabular}




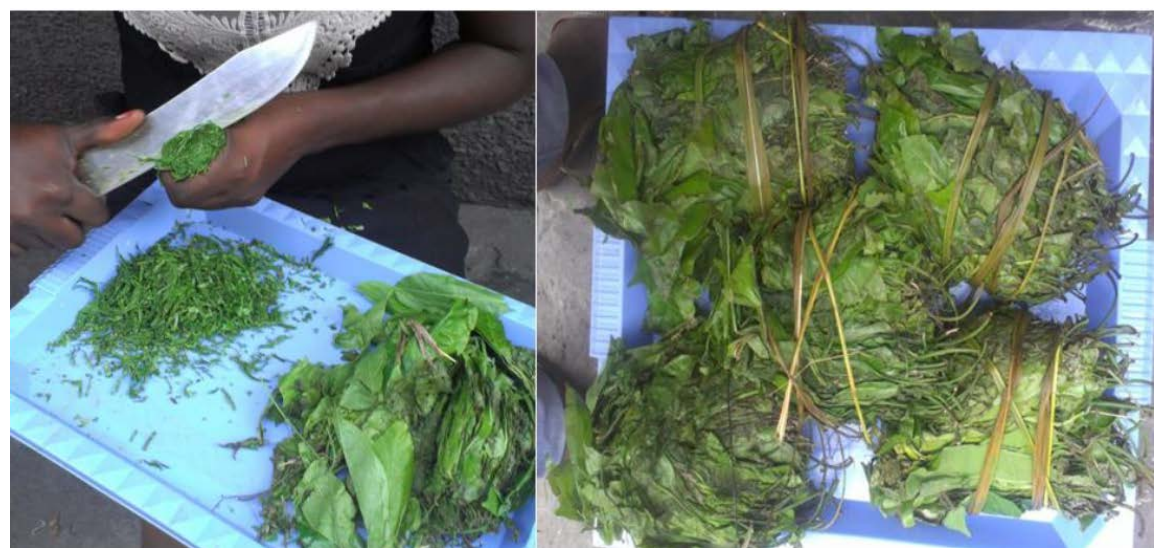

Figure 1. S. pynaertii.

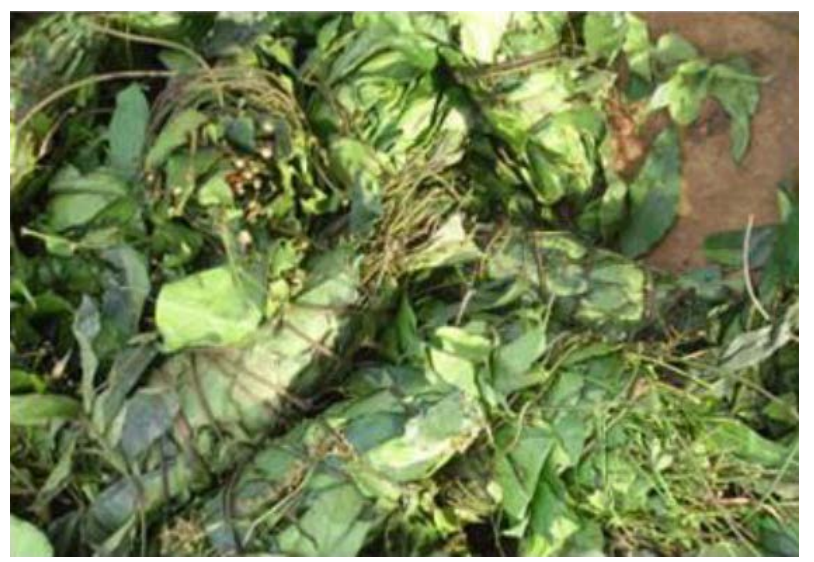

Figure 2. G. Africanum.

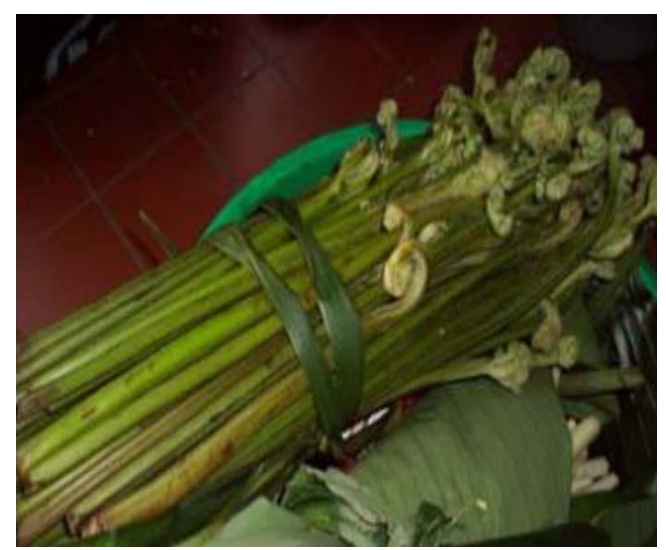

Figure 3. P. centrali-africanum.

\subsection{Data Analysis}

Descriptive analysis of all variables collected through the questionnaire survey was undertaken followed by logistic regression analysis of selected factors.

As one of the objectives of the study was to find out factors that influence the decision of commercializing NTFPs studied, a modeling approach of the logit type was adopted. It facilitates the manipulation of results estimating the maxi- 
mum vraisemblance. Likelihood [19] [20].

\subsection{Variables}

Dependent variable: Choice of commercialization of NTFP. Independent variables

Human factor: Age, Marital Status and Education level.

Social Factor: Relationship with suppliers, relationship with customers.

Market factor: Income, supply location, pricing, access to market.

Technical factor: access to credit, period of affluence, conservation method.

\section{Results}

\subsection{Descriptive Analysis}

Dependent variable: Distribution of respondents according to the choice of species.

Regarding the choice of species to be commercialized, it appears that the majority of respondents declared that the choice of a species is related to their cultural identity. This has proportions of $76.8 \%$ for $S$. pynaertii, $66.7 \%$ for $G$. africanum and $71 \%$ for $P$. centrali-africanum. It is difficult to begin a business without knowing the value of the product.

\subsection{Independent Variables}

\section{Human factor}

The distribution of vendors according to sex does not vary for $S$. pynaertii and $G$. africanum for which the activity is $100 \%$ female, while it is $97.1 \%$ for $P$. centrali-africanum. From the perspective of age, results show that NTFPs are mainly commercialized by individuals with an average age of 40 years and above, with $56.5 \%$ for $S$. pynaertii, $60.9 \%$ for $G$ africanum and $53.6 \%$ for $P$. centrali-africanum.

Regarding the marital status of the respondents, the sellers living with their spouses represent the most important class. Their percentage varies for $S$. pynaertii, G. africanum and P. centrali-africanum by $60.9 \%, 50.7 \%$ and $53.6 \%$ respectively. The distribution of respondents with high school certificate (education) is $40.6 \%$ for sellers of $S$. pynaertii; $33.3 \%$ for $G$. africanum and $44.9 \%$ for $P$. centrali-africanum. It follows that the majority of sellers do not have a high school certificate.

It is observed that $42 \%$ of sellers of $S$. pynaertii, $55.1 \%$ sellers of $G$. africanum and $60.9 \%$ sellers of $P$. centrali-africanum have 10 years of experience in the practice. This fidelity in the sales practice of these NTFPs shows that farmers find their account in meeting their needs within households.

\section{Social factors}

The results show that all respondents are linked to their suppliers only through a professional relationship. Therefore, kinship plays no role in the commercialization of NTFPs under study. The professional relationship is the 
unique relationship between sellers (respondents) to their customers. No other relationship is involved in these commercial exchanges.

Market factors

The respondents have relatively easy access to market, $75.4 \%$ for $S$. pynaertii, $50.7 \%$ for $G$. africanum and $40.6 \%$ for $P$. centrali-africanum. In terms of supply location, vendors of $S$. pynaertii and $G$. africanum are all sourcing in their respective markets, while $87 \%$ of $P$. centrali-africanum do so.

Prices are solely determined by the respondents themselves. There are differences regarding the daily average incomes. $68.1 \%$ of vendorsearn an average income of 5.7 USD from $S$. pynaertii, 82.6\% earn USD 10 from $G$. africanum, while $55.1 \%$ earn an average income of USD 4.7 from $P$. centrali-africanum.

\section{Technical factors}

The distribution of respondents according to access to credit shows that the percentage of sellers whose access to credit is relatively easy is very low, whether for sellers of $S$. pynaertii (11.6\%), G. africanum (10.1\%) or P. centali-africanum (4.3\%). These results show that vendors of NTFPs have almost no access to microcredit.

All the vendors of $S$. pynaertii, $G$. africanum and $P$. centrali-africanum affirm that the rainy season is the supply peak period. This is explained by the fact that during the rainy season, plants have a greater vegetative activity as compared to the dry season.

All responders declared having a preservation method for $S$. pynaertii and $G$. africanum while no respondent admitted having knowledge about any preservation method for $P$. centrali-africanum.

With regard to the difficulties encountered, the results show that on a scale ranging from 0 to 10 , the majority of respondents of $S$. pynaertii $(71 \%)$ and $G$. africanum (55\%) consider that the difficulties they faced did not exceed 2 out of 10; on the other hand, for the respondents of $P$. centrali-africanum it is the minority (31.9\%) that did not exceed 2 out of 10.

\subsection{Determinants of the Commercialization of NTFPs under Study}

A positive coefficient means that the probability increases with the increase of corresponding independent variable (20).

For $S$. pynaertii, age and marital status whose $\mathrm{P}$-values are less than 0.05 are explanatory factors determining the choice of commercialization. The signs of their estimated regression coefficients are 1.59305 and 1.65695 respectively. They translate the increase or the decrease probability of the choice of the commercialization of this product by individual (Table 2).

For G. africanum, it is the experience in the practice, with P-value less than 0.05 that appeared as the only explanatory factor determining the choice of its marketing. Its regression coefficient is 1.54529 .

The age, marital status, market access, place of supply and income with P-value less than 0.1 are explanatory factors determining the choice of marketing $P$. centrali-africanum. The signs of the estimated regression coefficients 
Table 2. Result of logistic regression.

\begin{tabular}{cccccccc}
\hline & \multicolumn{5}{c}{ Choice of Commercialization of NTFPs } \\
\cline { 2 - 7 } Variables & \multicolumn{2}{c}{ S. pynaertii } & G. africanum & \multicolumn{2}{c}{ P. centrali-africanum } \\
\cline { 2 - 7 } & Coefficient & P value & Coefficient & P value & Coefficient & P value \\
\hline Age & $-1.59305^{* *}$ & 0.0243 & $-0.08913 \mathrm{NS}$ & 0.8859 & $-1.15352^{*}$ & 0.0972 \\
Education level & $0.30316 \mathrm{NS}$ & 0.6883 & $-0.91938 \mathrm{NS}$ & 0.1469 & $0.66707 \mathrm{NS}$ & 0.3597 \\
Marital status & $1.65695^{*}$ & 0.0467 & $0.29545 \mathrm{NS}$ & 0.6502 & $-1.37438^{*}$ & 0.0779 \\
Experience & $-0.95864 \mathrm{NS}$ & 0.1793 & $1.5452^{*}$ & 0.0287 & $0.15816 \mathrm{NS}$ & 0.8306 \\
Access to market & $-0.60566 \mathrm{NS}$ & 0.4796 & $0.30022 \mathrm{NS}$ & 0.6511 & $-2.35922^{* * *}$ & 0.0041 \\
Supply Location & & & & & $-1.30486 *$ & 0.0795 \\
Income & -1.22998 & 0.1498 & $0.46041 \mathrm{NS}$ & 0.5473 & $1.76038^{* *}$ & 0.0477 \\
Access to credit & $0.01176 \mathrm{NS}$ & 0.9901 & $-0.44208 \mathrm{NS}$ & 0.6450 & $-2.19872 \mathrm{NS}$ & 0.1489 \\
Pricing & 0.56396 & 0.7048 & & & 2.38890 & 0.2151 \\
\hline
\end{tabular}

Legend: ${ }^{* *}$ Significant at $1 \%$; ${ }^{* *}$ significant at $5 \%$; ${ }^{*}$ significant at $10 \%$.

are $-1.15352,-1.37438,-2.35922,-1.30486$ and 1.76038 respectively. They translate the increase or the decrease of the probability of the choice of the marketing of this product by individual.

\subsection{Daily Profitability}

The profitability, which is the ratio between the profit of an activity and the amount of its expenses, constitutes a privileged element to evaluate the performance of an enterprise. The results presented here are calculated on the basis of estimates of the average quantities sold, the amount of cash earned, and the level of associated average costs. These results give then an idea of the role of this sector in the socio-economic situation of households (Table 3).

Taxes include daily State's tax, allocation fee for the place of establishment and warehouse fees.

The results of the financial calculations give the profit and the profitability of the 3 NTFPs under study, as follows: $5300 \mathrm{CDF}$ and $41.7 \%$ for $S$. pynaertii; $9300 \mathrm{CDF}$ and $86.9 \%$ for $G$. africanum; and $320 \mathrm{CDF}$ and $23.2 \%$ for $P$. centrali-africanum respectively. It shows that the commercialization of these NTFPs in Kinshasa is not only a support to traditional food habit, but it is really a lucrative activity that helps improve the living conditions of the vendors.

\subsection{Origin and Difficulties Related to the Trade of Studied NTFPs}

The NTFPs under study marketed in Kinshasa come from various places in the countryside [14] [16] [21]. The difficulties faced by the vendors are mainly the lack of loans and of adequate places where they can perform their activity without being inconvenienced, which lead the majority of them to sell their products on the ground along and in the streets. 
Table 3. Financial Calculation of $G$. africanum.

\begin{tabular}{cccc}
\hline Denomination & S. pynaertii & G. africanum & P. centrali-africanum \\
\hline Size of brunch (g) & 175 & 169 & 1000 \\
Number of brunches & 12 & 10 & 3.4 \\
Buying price/brunch (CDF) & 1000 & 1000 & 200 \\
Buying price/kg (CDF) & 5714 & 5917 & 200 \\
Total buying price (CDF) & 12,000 & 10,000 & 680 \\
Taxes (CDF) & 700 & 700 & 700 \\
Total expenses (CDF) & 12,700 & 10,700 & 1380 \\
Selling price/brunch (CDF) & 1500 & 2000 & 500 \\
Total sales (CDF) & $\mathbf{1 8 , 0 0 0}$ & $\mathbf{2 0 , 0 0 0}$ & $\mathbf{1 7 0 0}$ \\
Profit (CDF) & 5300 & 9300 & 320 \\
Profitability (\%) & 41.7 & 86.9 & 23.2 \\
\hline
\end{tabular}

$* 930 \mathrm{CDF}=1 \mathrm{USD}$.

\section{Discussion and Conclusion}

\subsection{Discussion}

NTFPs remain to this day one of the main sources of food, medicine and income for the rural and urban populations of the Democratic Republic of Congo, as [16] and [22] have reported, and our results which indicate that women are the most implicated in their trade, with $100 \%$ for G. africanum and S. pynaertii, and 99\% for $P$. centrali-africanum, are in accordance with [23] who has prospected this activity in 11 markets in Kinshasa and came up with a rate of $98 \%$.

Our results showing that all the vendors of and $87 \%$ of those who sell get their products on the spot are consistent with those of [23] who indicated that reducing transport costs makes easier and more lucrative the trade of NTFPs and encourages more people to undertake this activity. [13] also confirmed that the high distance from the supply point was incompatible with the desire to engage in NTFPs trade. This aspect appears more with the access to the market being an important explanatory factor for the choice of commercializing $P$. centrali-africanum. Indeed, being supplied locally with this very perishable product saves time, energy and prevents from the costs of transportation.

For $S$. pynaertii, our results show a close relationship between the commercialization of this product and the marital state of the vendors, in accordance with [13] who explained that married people were more likely to undertake this activity in order to diversify their sources of income.

The age appears also as a determining factor in the choice of commercializing S. pynaertii. This means that the younger an individual is, the more likely he is to market the product and vice versa. This is in accordance with [8] who observed that the trade in the hard conditions of Kinshasa is very demanding physically and requires good health, which make it more suitable for younger 
than for elder persons.

The experience in the trade of $G$. africanum is a major factor in pursuing this activity, because it provides those who have it with a better knowledge of the products and of their commercial circuits, and prevents them from some mistakes. These results are in accordance with [8] who showed how different and numerous are the characteristics of the products that a vendor has to take into account.

The profit which is the goal pursued by all traders seems to be a major factor in the choice of commercializing $P$. centrali-africanum, although the profit of this product is much less than the amount of 275 USD that [24] estimated as the contribution of $G$. Africanum trade to the monthly income of the household in Kinshasa.

\subsection{Conclusions}

This study was conducted in the city of Kinshasa, specifically in the Camp Luka, Gambela, Ngaba, Matadi-kibala, Selembao and Pascal markets, on a sample of 207 vendors of $S$. pynaertii, G. africanum and $P$. centrali-africanum. The work aimed to study the profitability of the trade of these NTFPs and analyze the factors determining the choice of their commercialization.

Statistical analysis helped to identify the variables that influence the commercialization of these NTFPs and showed that none of the studied variables is relevant explanation of the trade of all of them. The trade of $S$. pynaertii is influenced by the age and the marital status, whereas the experience is the factor influencing the choice to commercialize $G$. africanum. For P. centrali-africanum, the factors having an influence on the commercialization are the market access and the profit.

The results of the daily financial calculations give the profit and the profitability of the 3 NTFPs studied in the following way: 5300 FC (5.7 USD) and $41.7 \%$ for S. Pynaertii, 9300 FC (10 USD) and $86.9 \%$ for G. africanum; and 320 FC (0.34 USD) and $23.2 \%$ for P. centrali-africanum.

The constraints linked to the trade of these NTFPs are the lack of loans and of adequate places of implantation, the seasonality of the products and the lack of adequate infrastructures for storage and preservation.

\section{Conflicts of Interest}

The authors declare no conflicts of interest regarding the publication of this paper.

\section{References}

[1] Loubelo, E. (2012) Impact des produits forestiers non ligneux sur l'économie des ménages et la sécurité alimentaire: Cas de la République du Congo. Thèse de doctorat, Université de Rennes 2, Rennes, 260.

[2] Noubissie, E., Tieguhong, J.C. and Ndoye, O. (2008) Analyse des aspects socioéconomiques des produits forestiers non ligneux en Afrique Centrale. FAO, Rome, 
58.

[3] Tabuna, H. (2007) Commerce sous régional et internationaldes produits forestiers non ligneux alimentaires et desproduits agricoles traditionnels en Afrique Centrale: Etat deslieux et stratégie de développement. FAO, Rome, 139.

[4] Atangana, A.R., et al. (2014) Tropical Agroforestry. Springer, New York. https://doi.org/10.1007/978-94-007-7723-1

[5] Vermeulen, C., et al. (2011) Enjeux fonciers, exploitation des ressources naturelles et forêts des communautés locales enpériphérie de Kinshasa, RDC. Biotechnology, Agronomy, Society and Environment, 15, 535-544.

[6] Makumbelo, E., et al. (2008) Stratégie de valorisation des espèces ressources des produits non ligneux de la savane des environs de Kinshasa: II. Enquête ethnobotanique (aspects médicinaux). Tropicultura, 26, 129-134.

[7] Vantomme, P. and Gazza, S. (2010) Le défi de la sylviculture en faveur des produits forestiers non ligneux sous les tropiques: De la cueillette à l'agriculture? Bois \& Forêts de Tropiques, 304, 5-13. https://doi.org/10.19182/bft2010.304.a20447

[8] Biloso, A. and Lejoly, J. (2006) Etude de l'exploitation et du marché des produits forestiers non ligneux à Kinshasa. Tropicultura, 24, 183-188.

[9] Falconer, J. (1990) The Major Significance of Minor Forest Products: Examples from West Africa. Appropriate Technology, 17, 13-18.

[10] Bikoué, C.M. and Essomba, H. (2006) Gestion ressources naturelles fournissant les produits forestiers non ligneux en Afrique Centrale. Projet GCP/RAF/398/GER, Programme Produits Forestier Non Ligneux, No. 5. FAO, Rome.

[11] FAO (2001) Informations sur la sécurité alimentaire en RDC, No. 21, Rome. FAO, Rome.

[12] Shackleton, S., Shanley, P. and Ndoye, O. (2007) Invisible but Viable: Recognising Local Markets for Non-Timber Forest Products. International Forestry Review, 9, 697-712. https://doi.org/10.1505/ifor.9.3.697

[13] Biloso, A. (2008) Valorisation des produits forestiers non ligneux des plateaux de Bateke en périphérie de Kinshasa. Thèse de doctorat, Université Libre de Bruxelles, Bruxelles, 252.

[14] Biloso, A. (2010) Le savoir-faire local dans la valorisation alimentaire de la fougère (Pteridium centrali-africanum) à Kinshasa (RD Congo). In: Maesen, J., Onana, J.M. and Burgt, X., Eds., Systématique et Conservation des Plantes Africaines, Royal Botanic Gardens, 333-339.

[15] De Jong, W., Campbell, B.M. and Schröder, J.M. (2000) Sustaining Incomes from Non Timber Forest Products: Introduction and Synthesis. International Tree Crops Journal, 10, 267-275. https://doi.org/10.1080/01435698.2000.9753015

[16] Latham, P. and Konda, K.A. (2014) Plantes utiles du Bas-Congo. 3rd Edition, 409.

[17] FAO (1999) Les produits forestiers non ligneux et la création des revenus. FAO, Rome, 125.

[18] Gumuchian, H. and MArois, C. (2000) Initiation à la recherche en géographie. Aménegament developpement territorial, environnement. Presses de l'Université de Montreal, Montreal. https://doi.org/10.4000/books.pum.14790

[19] Hurlin, C. (2003) Econométrie des variables qualitatives. Cours de maîtrise d'économétrie. Université d'Orléans, Orléans, 59.

[20] Neupane, R.P., Sharma, K.R. and Tharpa, G.B. (2002) Adoption of Agroforestry in the Hills of Nepal: A Logistic Regression Analysis. Agricultural System, 72, 177-196. 
https://doi.org/10.1016/S0308-521X(01)00066-X

[21] Manirakiza, D., et al. (2009) Etude de base de la filière de Fumbwa (Gnetum africanum Welw) en RDC.

[22] Malaisse, F. (1997) Se nourrir en forêt claire africaine. Approche écologique et nutritionnelle. CTA, Wageningen.

[23] Toirambe, B. (2002) Utilisation des feuilles de Gnetum sp. dans la lutte contre l'insécurité alimentaire et la pauvreté des pays d'Afrique Centrale, cas de la RD Congo. FAO, Rome.

[24] FAO (2006) The State of the Food and Agriculture. FAO, Rome. 